\title{
Recent Advancement in Cooling Technologies of Solar Photovoltaic (PV) System
}

Jitendra B. Satpute

Research Scholar School of Mechanical engineering (SMEC), VIT University, Vellore,

India

John Rajan A.

Professor

School of Mechanical engineering (SMEC), VIT University, Vellore,

India
The temperature of Photovoltaic (PV) module rises by absorbed incident solar radiation and causes subsequent drop off in electrical efficiency. To overcome this ill effect, an appropriate material must be used to absorb the heat and maintain the temperature of $P V$ module. The purpose of present study is to review and understand various cooling techniques used to enhance cooling and electrical performance. The emphasis was placed on design and operating parameters like absorber configuration, flow pattern, flow rates, climatic conditions, radiation intensity, wind speed, thermal conductivity, glazing, concentration on the electrical and thermal characteristics. The reviewed papers include theoretical analysis, computer simulation, solar simulator and on-field experiments. The study states that the proper selection and utilization of cooling technology, design and process parameters are the key elements in the solar photovoltaic $(P V)$ system to achieve optimum performance.

Keywords: Photovoltaic; Module temperature; photovoltaic cooling technologies; Photovoltaic/Thermal (PVT)

\section{INTRODUCTION}

Technological innovation, industrial development improves standards of living of mankind and it is directly proportional to energy consumption. The energy from the sun is the main source of energy on the earth. The different forms of energy available are geothermal energy, hydro energy, tidal energy, solar energy, wind energy, oil, coal, natural gases and other fossil fuels. Unfortunately, the majority of the energy requirement of globe is met by fossil fuels such as coal, natural gases, and oils. Though these conventional fuels are predominant sources to generate usable energy but their limited capacity, harmful by-products $\left(\mathrm{CO}_{2}, \mathrm{CO}, \mathrm{NOx}, \mathrm{SOx}\right.$, particulate matters, ash, ODP, GHE, chemicals), geographical distribution are the main concerns and gives rise to many social, economic and environmental issues. Hence energy becomes an important aspect of technology which should be carefully studied and utilized. The more attention should be provided on all possible existing and new renewable energy technologies to avoid an ill effect of conventional sources.

As the word indicates, renewable energies are naturally occurring and can be renewed. The adaptation of renewable energy system helps to reduce fossil fuel dependency and minimize the negative impact on climate, environment and health. There are many researchers who signified that the solar energy is most potent source as compared to all renewable sources of energies [1]. The solar collectors are subcategorized in

Received: January 2018, Accepted: May 2018

Correspondence to: Dr John Rajan A

School of Mechanical Engineering,

VIT University, Vellore, India

E-mail: ajohnrajan@gmail.com

doi:10.5937/fmet1804575S

(C) Faculty of Mechanical Engineering, Belgrade. All rights reserved solar thermal, solar PV and solar Photovoltaic/Thermal (PVT) based on the energy collection.

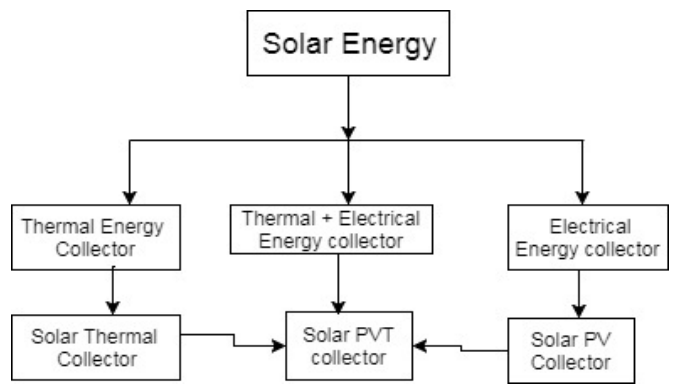

Fig 1. Classification of Solar energy collector based on energy Conversion

With the discovery of photovoltaic effect by French scientist Edmond Becquere in 1839, the first solar cell was designed by Charles Fritts with an efficiency of 1$2 \%$ in 1883. The solar module gives the best performance at specified operating temperature. As the surface temperature of PV module increases, semiconductor's properties tend to shift and thereby increasing the current and trade off in a drop of voltage assimilating reduction in power output. Much excess temperature may damage PV module. It means that temperature of PV module increases by absorbed solar radiation that is unable to convert into electrical power and result in a decreasing electrical efficiency. In the study performed by E. Skoplaki et al [2], reduction of $0.45 \%$ in relative efficiency with a rise $1^{\circ} \mathrm{C}$ in temperature of crystalline-Silicon PV module was seen. To conquer this ill effect, an appropriate material must be used to absorb the heat and maintain the temperature of $\mathrm{PV}$ cell as per manufacturer specification. It gives rise to a new technology called PVT or hybrid PV technology for generation of electricity (by photovoltaic effect) and thermal energy (by absorbing heat from PV 
through cooling medium). The concept of the hybrid PVT collector was proposed in 1978 by Kern and Russel [3].

T. T. Chow [4] performed a review on recent advancement in PVT hybrid solar technology and conclude that the PVT has significant marketplace in coming years.

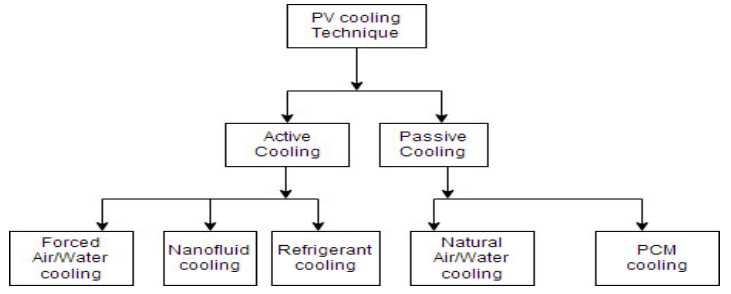

Fig 2. Classification of PV cooling techniques

The present work describes technological enhancement in cooling technologies as listed above with emphasis on design and operating parameters like different absorber configuration and flow pattern, flow rates, climatic conditions, radiation intensity, wind speed, thermal conductivity, glazing on the electrical and thermal performance of collector in the last decade.

\section{AIR BASED COOLING TECHNOLOGY}

Ease of availability, low cost and wide direct applications are the encouraging factors for favouring air as a cooling medium of PV module. The study on air based PVT [5] reveals that the front and back surface temperatures of PV module were crucial parameters for electrical performance. They concluded that the clear sky with minimum wind velocity gave favourable PVT performance. Many studies were performed to investigate and improve a performance of PVT considering variation in operating parameter and absorber design. $\mathrm{J}$ $\mathrm{K}$ Touni et al [6] developed six different numerical models of PVT air collector. i. e. reference PVT, PVT with a thin metal sheet of black colour Aluminium and PVT with fin considering with and without glazed configuration. Outlet temperature, mass flow rate, incident radiation, channel depth, collector length and exit vent were the parameter considered for study. Findings support use of glazing and fin for better performance of PVT.

A Shahsavar et al [7] developed a theoretical model of PVT for improvement of heat extraction performance at natural and forced circulation with experimental setup for validation. A thin metal sheet of aluminium was inserted into the flow passage of duct and comparative study was performed with and without glazed configuration. Results again agreed that glazed and force circulation improved the performance due to improved heat transfer. In order to improve the active PV cooling, experimental set up was designed with an extended surface in a duct by H.G. Teo et al [8] and the results were compared with PV without cooling. In another investigation by Arvind Tiwari et al [9], PVT-tedlar, and PVT- without tedlar had been studied considering with and without glazed configuration. Analytical expressions were derived and validated with experimentation. It was seen that PVT- without tedlar found to be effective configuration throughout the analysis. The investigation [10] was also performed in New Delhi,
India to compare overall performance of glass to glass PVT with glass to tedlar PVT. The overall performance of glass to glass PVT was found better due to higher thermal performance.

.Table. 1 Comparison of performance parameters under various test condition with air based cooling

\begin{tabular}{|l|c|c|c|}
\hline Absorber \& flow type & $\begin{array}{c}\text { flow rate } \\
\text { of air }\end{array}$ & $\begin{array}{c}\text { Electrical } \\
\text { Efficiency } \\
\text { (\%) }\end{array}$ & $\begin{array}{c}\text { Thermal } \\
\text { Efficiency } \\
\text { (\%) }\end{array}$ \\
\hline $\begin{array}{l}\text { Double pass duct \& fin } \\
\text { [11] }\end{array}$ & $0.015 \mathrm{~kg} / \mathrm{s}$ & 4 & 69 \\
\hline Single pass duct [12] & $\begin{array}{c}0.1 \\
\mathrm{~kg} / \mathrm{s}\end{array}$ & 8.4 & 42 \\
\hline $\begin{array}{l}\text { Single pass with thin } \\
\text { metal sheet [13] }\end{array}$ & $\begin{array}{c}0.13 \\
\mathrm{~kg} / \mathrm{s}\end{array}$ & 9.5 & 50 \\
\hline $\begin{array}{l}\text { Single pass rectangle } \\
\text { duct [14] }\end{array}$ & $\begin{array}{c}0.0287 \\
\mathrm{~kg} / \mathrm{s}\end{array}$ & 10.02 & 54.7 \\
\hline $\begin{array}{l}\text { Single pass sheet and } \\
\text { fin [15] }\end{array}$ & $\begin{array}{c}0.14 \\
\mathrm{~kg} / \mathrm{s}\end{array}$ & 13.75 & 56.19 \\
\hline $\begin{array}{l}\text { Array of duct with fin } \\
\text { [16] }\end{array}$ & $\begin{array}{c}0.02-0.14 \\
\mathrm{~kg} / \mathrm{s}\end{array}$ & $10.1-10.9$ & $45-60$ \\
\hline Single pass duct [17] & $\begin{array}{c}0.03-0.05 \\
\mathrm{~kg} / \mathrm{s} \mathrm{m}\end{array}$ & $10.6-12.2$ & $28-55$ \\
\hline $\begin{array}{l}\text { Single pass sheet \& } \\
\text { fin[18] }\end{array}$ & $\begin{array}{l}0.05 \\
\mathrm{~kg} / \mathrm{s} / \mathrm{m}^{2}\end{array}$ & $9-10$ & 52 \\
\hline Single pass duct [19] & $\begin{array}{c}1.0 \\
\mathrm{~m} / \mathrm{s}\end{array}$ & 10.01 & 17.18 \\
\hline Single pass duct [20] & $\begin{array}{c}0.0667 \\
\mathrm{~m}^{3} / \mathrm{s}\end{array}$ & 15 & 22 \\
\hline
\end{tabular}

Though air based PVT is extensively used and popular cooling technology, its lower thermal conductivity reduces the heat transfer rate causing lower thermal performance. For increasing heat transfer rate, air cooling requires high grade energy which involves operating cost addition.

\section{WATER BASED COOLING TECHNOLOGY}

Water is the conventional cooling medium used for many industrial and domestic purposes such as internal combustion engine, steam power plant, chemical plant, and refineries. Water is inexpensive, non-toxic and has high heat storage capacity. The effectiveness of water to cool PV module was studied by [21] in the hot climatic condition of Dhahran, Saudi Arabia. A numerical model was developed and compared with experimental work for validation. Results proved that the water cooling reduced the PV surface temperature by $20 \%$ which helped to raise PV module efficiency by $9 \%$. The performance analysis of PVT water collectors was done by Ahmad Fudholi et.al. [22] and proved that the efficiency of the PV module increase when the temperature decrease. It was also seen that decrement in temperature is not a linear with increment in the mass flow rate.

A comparative study between non-cooled PV, water cooled, Ethylene Glycol (EG) cooled, and water- EG mixture cooled PV was performed by Blessy Joy et al [23]. The serpentine tube configuration was used to absorb heat from PV module and performance is evaluated on the basis of electrical and thermal efficiencies. It was seen that efficiency of PVT exponentially increases with increase in thermal 
conductivity of coolant. The higher thermal conductivity of water improved the overall efficiency of PVT by $25 \%$ compared to EG. In order to improve heat transfer rate, Masoud Rahimi et al [24] proposed micro channel absorber with a hydraulic diameter of $0.667 \mathrm{~mm}$. An experimental investigation was performed to compare the maximum electrical power generation. It was seen that micro channel absorber arrangement improved the power generation by $30 \%$. A new configuration of PVT for extracting more heat was proposed by $\mathrm{K}$ Touafek et al[25]. The theoretical model of plate of galvanized steel and tube integration was developed as an absorber for heat extraction and validated performance with experimental work. The modified absorber was characterized by better heat absorption capability and lower production cost and proved good alternative for conventional PVT system. The study was also performed by [26] with low cost galvanized steel material as an absorber. They developed theoretical model with two new different absorber configurations such as parallel vertical tube and enclosure type. The result favoured use of parallel vertical tube absorber than enclosure due to higher energy saving.

The thermal and electrical performance optimization of the PVT collector was performed by Niccolo Aste et al [27]. He optimized the PVT performance by choosing appropriately thermo-electric configuration of the collector. A mathematical model was developed by W. A. J. Jaysuriya et al [28] to study effect of sensitivity of design, climate condition and operating parameters on performance of PVT. Different configurations based on cooling fluid and arrangement of glass and tedlar layer were proposed such as glass to glass PV module with air flow above the absorber plate, glass to glass PV module with air flow below the absorber plate, glass to tedlar PV module with air flow below the absorber plate, glass to glass PV module with water flow below the absorber plate and glass to tedlar PV module with water flow below the absorber plate. The result showed that glass tedlar water collector was found to be better configuration in performance compared to others. Authors also highlighted importance of operating parameters like wind speed, solar radiation, mass flow rate, fluid temperature and need of their optimisation to achieve optimum efficiency.

Domestic application of PVT in Kenya was studied by [29]. They estimated daily electrical energy demand and hot water requirement for family of five persons. The TRNSYS simulation was performed to determine optimum flow rate of water to satisfy estimated energy requirement. It was found that $25 \mathrm{LPH}$ was optimum flow rate providing combined efficiency of 37-62\% with payback period of investment was five years. Techno economic performance of PVT was studied by [30] and compared with PV, Solar Water Heater (SWH), and $\mathrm{PV}+\mathrm{SWH}$ system. Authors evaluated economic parameters like Simple Payback Period (SPP), Internal Rate of Returns (IRR), and Savings to Interest Ratio (SIR). This analysis showed that $\mathrm{PV}+\mathrm{SWH}$ system was slightly more favourable over PVT but considering area requirement, PVT produced almost same quantity of energy on half of area that $\mathrm{PV}+\mathrm{SWH}$ required.
Table. 2 Comparison of performance with different absorber and flow rate for water based cooling

\begin{tabular}{|l|c|c|c|}
\hline \multicolumn{1}{|c|}{$\begin{array}{c}\text { Absorber \& flow } \\
\text { type }\end{array}$} & $\begin{array}{c}\text { Flow rate } \\
\text { of water }\end{array}$ & $\begin{array}{c}\text { Electrical } \\
\text { Efficiency } \\
\text { (\%) }\end{array}$ & $\begin{array}{c}\text { Thermal } \\
\text { Efficiency } \\
\text { (\%) }\end{array}$ \\
\hline $\begin{array}{l}\text { Stainless Steel tubes } \\
\text { with different flow } \\
\text { patterns [31] }\end{array}$ & $\begin{array}{c}0.01 \\
\mathrm{~kg} / \mathrm{s}\end{array}$ & 11.98 & 50.12 \\
\hline $\begin{array}{l}\text { Copper tube in } \\
\text { Aluminium box [32] }\end{array}$ & $\begin{array}{c}0.06 \\
\mathrm{~kg} / \mathrm{s}\end{array}$ & $5-6$ & $33-64$ \\
\hline $\begin{array}{l}\text { Copper tube and sheet } \\
\text { with Aluminium } \\
\text { parallel duct [33] }\end{array}$ & $\begin{array}{c}0.03-0.06 \\
\mathrm{~kg} / \mathrm{s}\end{array}$ & 11.8 & 40.7 \\
\hline $\begin{array}{l}\text { Stainless Steel round \& } \\
\text { hollow shape absorber } \\
\text { [34] }\end{array}$ & $\begin{array}{c}0.11- \\
0.041 \mathrm{~kg} / \mathrm{s}\end{array}$ & 13.8 & 54.6 \\
\hline $\begin{array}{l}\text { Aluminium roll bond } \\
\text { absorber [35] }\end{array}$ & $\begin{array}{c}0.055- \\
0.066 \mathrm{~kg} / \mathrm{s}\end{array}$ & $6-14.2$ & $29-21.8$ \\
\hline $\begin{array}{l}\text { Aluminium alloy box } \\
\text { structure [36] }\end{array}$ & $\begin{array}{c}75-95 \mathrm{~kg} / \\
\mathrm{m}^{2}\end{array}$ & $9-11$ & $45-52$ \\
\hline $\begin{array}{l}\text { Aluminium alloy tube } \\
\text { sheet [37] }\end{array}$ & $\begin{array}{c}66.1-75 \\
\mathrm{~kg} / \mathrm{m}^{2}\end{array}$ & $7.84-13.60$ & $38-65.23$ \\
\hline $\begin{array}{l}\text { Aluminium alloy flat } \\
\text { box [38] }\end{array}$ & $65.2 \mathrm{~kg} / \mathrm{m}^{2}$ & $3.96-5.42$ & $\begin{array}{c}35.80- \\
51.95\end{array}$ \\
\hline $\begin{array}{l}\text { Aluminium roll bond } \\
\text { flat absorber [39] }\end{array}$ & $72 \mathrm{~kg} / \mathrm{h} / \mathrm{m}^{2}$ & 8.7 & 79 \\
\hline $\begin{array}{l}\text { Tube absorber with } \\
\text { covered sheet [40] }\end{array}$ & $\begin{array}{c}10 \\
\mathrm{~kg} / \mathrm{h} / \mathrm{m}^{2}\end{array}$ & 9.96 & 24.3 \\
\hline $\begin{array}{l}80 \\
\text { Stainless Steel square } \\
\text { channel [41] }\end{array}$ & $\begin{array}{c}80 \\
\mathrm{~kg} / \mathrm{h} / \mathrm{m}^{2}\end{array}$ & 13.5 & 56.5 \\
\hline $\begin{array}{l}\text { Copper rectangular } \\
\text { pipes [42] }\end{array}$ & $\begin{array}{c}1.5 \times 10^{-6} \\
\mathrm{~m}^{3} / \mathrm{s}\end{array}$ & $11.5-12.3$ & $58.8-61.7$ \\
\hline $\begin{array}{l}\text { Roll bond type } \\
\text { absorber with layer of } \\
\text { polymer [43] }\end{array}$ & $\begin{array}{c}1.1 \times 10^{-6} \\
\mathrm{~m}^{3} / \mathrm{s}\end{array}$ & 10.5 & 72.8 \\
\hline
\end{tabular}

Abundant availability and countless necessitate of hot water for domestic and industrial application water is dominant cooling medium used in PVT. Water cooling has the constraint of lower thermal conductivity, fouling of impurity inside duct, need of electricity to augment turbulence and heat transfer.

\section{PHASE CHANGE MATERIAL (PCM) BASED COOLING TECHNOLOGY}

The application of PCM for cooling of the photovoltaic system was initially investigated by Stultz and Wen in 1977 [44]. They found PCM cooling as a useful technique and can be enhanced by improving thermal conductivity to absorb higher heat from the PV module. Though the first investigation was performed in 1977, enormous research and development studies on PCM as a cooling tool were originated in last decade. One dimensional energy balance model was developed by [45] to predict worldwide perspective of PCM assisted PVT technology. Regions wise study was performed and concluded that the high isolation and less climatic variation were the promising parameters for implementing a PCM-PVT technology. The increment of $6 \%$ in energy output was achieved in Mexico and eastern Africa whereas 5\% in Central and South America, Africa, Arabia, Southern Asia and the Indonesia with PCM cooling. Research also highlighted need of further research for advancement and cost effective solution. A 
Hasan et al [46] proposed PV with paraffin based RT40 PCM for an extremely hot climate of UAE to evaluate its energy performance throughout the year. A conjugate heat transfer model was developed and validated with experimental work. The work signifies that the melting and solidification of PCM determine an extent of ability to cool PV; as less cooling was observed in cool months compared to hot months. The result provide concrete base to use of PCM-PVT in the hot climate as electrical energy yield was enhanced by $5.9 \%$.

An investigation of PCM based PVT with the metal fin configuration in an absorber to improve cooling was studied by M.J. Huang et al [47]. Three paraffin base PCM Waksol A, RT27, and RT35 were filled in absorber by $85 \%$ volume. It has been found that using RT27 and internal fin, significant reduction in the temperature rise was achieved.

Maria C Browne et al [48] performed comparative indoor investigation between PCM (Capric- Palmitic)PVT, PVT-water, and non-cooled PV collector. A stainless steel container with copper tubing was designed to pass water and PCM. Result concluded that PVT-PCM has considerable high heat storage capacity compare to PVT-water under the given condition. Another comparative study between PCM1-PVT (Eutectic mixture of capric-palmitic acid), PCM2-PVT (Salt hydrate $\mathrm{CaCl}_{2}-6 \mathrm{H}_{2} \mathrm{O}$ ) and non-cooled PV collector was studied by [49]. The two different climatic conditions as hot climate (Vihari, Pakistan) and a cold climate (Dublin, Ireland) were considered for investigation. Metallic PCM container was attached to the back of PV with internal fins. Result concluded that PCM2-PVT performed better to achieve higher temperature drop and power saving in Vihari, Pakistan. It has been also concluded that PCM-PVT performs better at hot and stable climatic conditions. In the meantime, M C Browne et al [50] also studied the potential of PCM for effective thermal management of $\mathrm{PV}$, concentrated $\mathrm{PV}$ and building integrated PV system. Work revealed that the PCM was a useful cooling technique to improve the performance and highlighted need of study in solidification and discharge characteristics of PCM.

Ewald Japs et al [51] performed an experimental study with non- cooled PV, commercial paraffin based PCM RT28 (thermal conductivity $(\mathrm{k})$ of $2.4 \mathrm{~W} /(\mathrm{mK})$ and same PCM (thermal conductivity of $0.19 \mathrm{~W} /(\mathrm{mK})$ The thermal conductivity of RT 28 was increased by the use of expanded graphite. Results confirmed that higher thermal conductivity of PCM should be preferred to achieve high-temperature drop and yield. A similar type of study [52] was intended to study the effect of pure PCM (thermal conductivity of $0.18 \mathrm{~W} / \mathrm{mK}$ and combine PCM (PCM (70\%), copper $(20 \%)$, graphite $(10 \%)$, (thermal conductivity of $95.38 \mathrm{~W} / \mathrm{mK}$ ) on the electrical and thermal behaviour of PV module. It was seen that thermal conductivity is proportional to electrical performance. The combined PCM and pure PCM improved the electrical efficiency by an average of $5.8 \%$ and $3 \%$ respectively

The effect of inclination on the cooling of PV was thoroughly studied by [53]. The absorber was designed with R25 PCM and incorporated with rectangular fins.
The angle of inclination was varied from 0 degrees to 90 degrees to vertical. It was observed that natural convection was dominant till 45-degree inclination and thereafter conduction played the dominant role. Investigation recommend smaller angle of inclination (lower than 45 degrees) for better cooling of PV.

$\mathrm{Di} \mathrm{Su}$ et al [54] highlighted the effect of position of the PCM layer and thickness of PCM on the dynamic characteristics of PVT. PV module temperature, air outlet temperature, electrical power, thermal power were simulated and evaluated for dynamic performance. Result conferred that upper layer of PCM with $3 \mathrm{~cm}$ layer thickness significantly improved the performance of collector for current design.

Ewa Klugmann-Radziemska et al [55] also performed the experimentation with PCM to stabilize PV module temperature. Paraffin 42-44, Rubitherm RT22 and Ceresin PCM were used for experimentation. Different configurations of PCM-PVT were proposed with varying layer thickness as well with and without water cooling. Best results of temperature stabilization was achieved for Paraffin 42-44 PCM of $2 \mathrm{~mm}$ thickness with water cooling configuration. They also highlighted concerns of water pumping, corrosion and increased weight associated with configuration.

Sajan preet et al [56] performed the experiments aiming to improve the performance of PV module. Three configurations of absorber as non- cooled PV, water based PVT with double absorber plate and water based PVT integrated with PCM (paraffin wax RT30) were proposed. The electrical and thermal performances were studied at varying mass flow rates. Findings concluded that water based PCM-PVT achieved 53\% temperature decrement and proved most effective technique compared with non- cooled PV at higher mass flow rate of $0.031 \mathrm{~kg} / \mathrm{s}$.

Passive cooling of PV with PCM is found superior as it provides higher energy storage density and silent cooling operation. The higher cost associated with preparation of PCM and its thermo physical properties are the main area of concern and further study is required for successful deployment in PCM based cooling.

\section{NANOFLUID BASED COOLING TECHNOLOGY}

Nanofluids are composite fluids involving properties of base fluid and enhanced properties of solute. It is an evolution of fluids which exhibit improved thermal conductivity of base fluid. Basically these fluids involves nanoparticles which posses high surface area to volume ratio. Also the lot of boom in research is observed in PVT technology by using nanofluids.

The introduction of nanotechnology provides a new era of fluids of enriched properties. The $\mathrm{Al}_{2} \mathrm{O}_{3}$-Water nanofluid was proposed by Sundermadji et al [57] to investigate heat transfer characteristics in double pipe heat exchanger. Experimentations were performed at varying volume concentration of $0.15 \%, 0.25 \%$, and $0.5 \%$ of nanoparticles. It was found that increasing nanoparticles concentration enhances convective heat transfer but it also raises slight pressure drop.

Outdoor investigation and exergy analysis of single slope solar still was performed by Madhu. B. et al [58] 
with $\mathrm{Al}_{2} \mathrm{O}_{3}, \mathrm{CuO}$ and $\mathrm{TiO}_{2}$ nanoparticles. The water was used as base fluid and volume concentration was varied from $0.05 \%$ to $0.2 \%$. A result justifies use of higher concentration for attaining higher yield. During the experimentation, maximum yield was obtained from $\mathrm{Al}_{2} \mathrm{O}_{3}$-water nanofluid. Natasha E.Hjerrild et al [59] performed an investigation to study PVT enhancement using selectively absorbing nanofluid of core-shell silver silica $\left(\mathrm{Ag}-\mathrm{SiO}_{2}\right)$ nanodiscs and Carbon Nanotubes $(\mathrm{CN})$. This combination resulted in incremental overall efficiency by $30 \%$.

Ali H.A.Al-Waeli et al [60] did a comparative study of nanoparticles $\mathrm{Al}_{2} \mathrm{O}_{3}, \mathrm{CuO}$ and $\mathrm{SiC}$ with water as a base fluid to evaluate and compare efficiency of PVT collectors. The experimentations were performed in indoor lab using a modified MINI-EEST simulator. The results showed that $\mathrm{SiC}$ had the highest overall efficiency and greater stability among all nanoparticles.

Nooshin Karamiet et al [61] conducted experiments to investigate the cooling performance with varying concentration of Bohemite with water as base fluid and compared with water based PVT. The straight and helical types of channels were used as an absorber to extract heat. Results showed that the presence of nanoparticle decreased an average temperature of PV module and enhanced electrical performance. The highest decrement in an average temperature of PV module at $0.1 \%$ concentration was found with helical channel which also leads to increase in electrical efficiency.

The influence of concentration, type of nanofluids and base fluid on thermal and electrical performance was also studied by Oussama Rejeb et al [62]. The numerical model for three different climatic conditions of France, Iran and Tunisia was developed and validated with experiments. The two nanoparticles of $\mathrm{Al}_{2} \mathrm{O}_{3}$ and $\mathrm{Cu}$ with concentration $0.1 \%, 0.2 \%$ and $0.4 \%$ by weight with pure water and ethylene glycol as base fluids were considered for experimentation. They concluded that pure water provides higher performance than ethylene glycol and $\mathrm{Cu}$-Water nanofluid gave the highest thermal and electrical efficiency compared to other nanofluid at Monastir (Tunisia) climatic condition.

A comparative study among natural cooling, forced air cooling, water cooling and $\mathrm{SiO}_{2}$-Water, $\mathrm{Fe}_{3} \mathrm{O}_{4}$-Water nanofluid cooling was studied by Shohreh Soltani et al [63]. It was observed that the nanofluids proved as a better cooling option than the conventional cooling methods. Due to higher heat transfer coefficient from $\mathrm{SiO}_{2}$-Water nanofluid, it was found to be favourable cooling medium among all. Hashim Hussein et al [64] tinted the importance of optimum concentration ratio for best potential performance. The indoor investigation was performed using $\mathrm{Al}_{2} \mathrm{O}_{3}$-water nanofluid from $0.1 \%$ to $0.5 \%$ concentration ratio with the circulated pipes as absorber located below the PV module. At optimum concentration ratio of $0.3 \%$, substantial temperature fall was noted which resulted in enhanced electrical efficiency of $12.1 \%$.

The latest study by Mohammad Sardarabadi et al [65] was performed with the combination of nanofluid (ZnO-water by $0.2 \% \mathrm{wt}$ ) and PCM (paraffin wax) as a cooling medium. The electrical and thermal performance of this modified coolant were compared with water based PVT and non-cooled PV. Result concluded that nanofluid based PV-PCM coolant reduced temperature of $\mathrm{PV}$ by 16 degree and electrical output increased by $13 \%$ compared to non-cooled PV collector.

Table. 3 Comparison of performance with various different nanofluids and bending

\begin{tabular}{|c|c|c|c|c|}
\hline $\begin{array}{c}\text { Nanofluid } \\
\text { and } \\
\text { Reference }\end{array}$ & $\begin{array}{c}\text { Blending } \\
(\%)\end{array}$ & flow rate & $\begin{array}{c}\begin{array}{c}\text { Electrical } \\
\text { efficiency } \\
(\%)\end{array} \\
\end{array}$ & $\begin{array}{c}\text { Thermal } \\
\text { efficiency } \\
(\%)\end{array}$ \\
\hline $\begin{array}{l}\text { CuO-Water } \\
{[66]}\end{array}$ & $\begin{array}{c}0.05 \% \text { by } \\
\text { vol }\end{array}$ & $\begin{array}{l}0.01 \\
\mathrm{~kg} / \mathrm{s}\end{array}$ & 7.62 & 28.22 \\
\hline $\begin{array}{l}\text { Silver- } \\
\text { Deionised } \\
\text { water[67] }\end{array}$ & $\begin{array}{c}0.5 \% \text { by } \\
\text { vol }\end{array}$ & $\begin{array}{c}0.039 \\
\mathrm{~kg} / \mathrm{s}\end{array}$ & 13.2 & 60.8 \\
\hline $\begin{array}{l}\mathrm{SiO}_{2} \text {-Water } \\
{[68]}\end{array}$ & \multirow{3}{*}{$\begin{array}{c}0-2 \% \text { by } \\
\text { weight }\end{array}$} & \multirow{3}{*}{$\begin{array}{c}0.170 \\
\mathrm{~kg} / \mathrm{s}\end{array}$} & 10.30 & 65.93 \\
\hline $\begin{array}{l}\mathrm{TiO}_{2} \text {-Water } \\
{[68]}\end{array}$ & & & 10.97 & 66.93 \\
\hline $\begin{array}{l}\text { SiC-Water } \\
{[68]}\end{array}$ & & & 13.52 & 68.21 \\
\hline $\begin{array}{l}\mathrm{TiO}_{2} \text {-Water } \\
{[69]}\end{array}$ & \multirow{3}{*}{$\begin{array}{c}0.2 \% \text { by } \\
\text { weight }\end{array}$} & \multirow{3}{*}{$\begin{array}{c}8.3 \times 10^{-3} \\
\mathrm{~kg} / \mathrm{s}\end{array}$} & 13.62 & 44.34 \\
\hline $\begin{array}{l}\mathrm{ZnO}-\text { Water } \\
\text { [69] }\end{array}$ & & & 13.58 & 46.05 \\
\hline $\begin{array}{l}\mathrm{Al}_{2} \mathrm{O}_{3} \text {-Water } \\
{[69]}\end{array}$ & & & 13.43 & 36.66 \\
\hline $\begin{array}{l}\mathrm{Al}_{2} \mathrm{O}_{3} \text {-Water } \\
{[70]}\end{array}$ & $\begin{array}{l}2 \% \text { by } \\
\text { weight }\end{array}$ & $\begin{array}{c}1.1 \times 10^{-5} \\
\mathrm{~m}^{3} / \mathrm{s}\end{array}$ & 13 & 45 \\
\hline $\begin{array}{l}\mathrm{Fe}_{3} \mathrm{O}_{4} \text {-Water } \\
\text { [71] }\end{array}$ & $\begin{array}{c}1 \%-2 \% \\
\text { by weight }\end{array}$ & $\begin{array}{c}1.1 \times 10^{-5} \\
\mathrm{~m}^{3} / \mathrm{s}\end{array}$ & $6.68-6.81$ & $\begin{array}{l}70.41- \\
74.96 \\
\end{array}$ \\
\hline
\end{tabular}

Higher thermal conductivity compare to conventional air and water, nanofluid based cooling enhanced heat dissipation due to high surface area. In nanofluid based cooling; solute, nanoparticles, blending, stability over a long period, thermo physical properties, and cost associated with preparation are the key variables that decide the electrical and thermal performance.

\section{REFRIGERANT BASED COOLING TECHNOLOGY}

In recent years, researcher proposed non-conventional refrigerant for cooling PV module. During the operation, low temperature, low-pressure liquid refrigerant passed through the back of PV panel to extract heat from PV module and get converted into a gaseous phase. This gaseous phase refrigerant is compressed in the compressor up to its desired delivery pressure and further passed through the condenser. Receiver and throttling valve are placed between condenser and evaporator to regulate required flow to maintain cooling temperature. After throttling of refrigerant through throttle valve, the refrigerant is circulated in an evaporator to extract heat and cycle is repeated. The heat exchange between water and refrigerant increases the temperature of water and can be used for any domestic or industrial water heating application. Such solar integrating heat pumps are also known as Heat Pump Water Heating (HPWH) or Solar Assisted Heat Pump (SAHP). R Daghigh et al concluded in his study [72] that refrigerant based absorber provides the better cooling effect in PVT and able to provide electrical efficiency of $13.4 \%$ simultaneously with Coefficient of 
Performance (COP) of 8.3. Some of the recent developments in refrigerant based cooling were discussed in the following context.

Honbing et al [73] performed an investigation with $\mathrm{R} 134 \mathrm{a}$ as a refrigerant to improve cooling and electrical performance. The low evaporating temperature of R134a makes it suitable for absorbing heat and helped to cool PV module. A glass vacuum tube type PV module heat pump system was manufactured to investigate the effectiveness of refrigerant based coolant and effect of varying solar radiation, condenser water flow rate and condenser water inlet temperature on COP. With refrigerant cooling, electrical efficiency was augmented by $1.9 \%$ compared to conventional non-cool PV collector. Similar performance analysis of PVTHPWH with R134a was also carried out by Huan Liang Tsai [74]. He proposed MATLAB based numerical model to enhance PVT efficiency and heat pump COP and validated with field experiment at Taiwan. His investigation concluded that on a sunshine day, the average overall efficiency of $86.29 \%$ and COP of 7.09 was achieved with the proposed design.

Feng Shan et al [75] also proposed environmental friendly R410a refrigerant for PV cooling. A dynamic model was constructed to analyze the influence of evaporator temperature and radiation intensity on electrical and thermal performance under climatic condition of Nanjing, China. With the same type of refrigerant, experimental investigation had been performed by [76]. A novel parallel laid micro channel structure was designed with a reduced cross sectional area to enhanced vapour flow velocity and vapour evaporation rate which result in the higher performance of the system. With this novel design average overall efficiency of $69.7 \%$ and COP of 4.7 was achieved. An experiment was also performed with R22 refrigerant for cooling the PV and utilization of heat energy to space heating [77]. A novel mini channel absorber with small cross sectional area was design to improve heat transfer. It was found that such PVT arrangement had average overall efficiency of $45 \%$ and COP of 4.9

Attila Bai et al [78] highlighted technical and economic impact with refrigerant based cooling. Study deals with water sprinkling and refrigerant for cooling PV cell under Hungarian condition and performance was compared with non cooled PV. Performance results favoured use of water sprinkling technique for cooling in a technical and economic sense. Considering electricity consumption for coolant circulation, net electrical performance was found to be $12 \%$ for sprinkling whereas it was negative for refrigerant.

Due to better heat transfer characteristics, refrigerant based cooling is prefered in current years but high initial and operating costs, power consumption, refrigerants thermo physical characteristics and environmental characteristics need to be further studied in details.

\section{CONCLUSION}

It is seen that cooling of PV assists to reduce PV surface temperature and results in improved electrical and thermal performance. Following are the concluding remarks from existing literature review.
Many comparative studies were performed and endorsed PV cooling for overall performance improvement per unit area. Performance of PVT mainly depends on the variables like incident solar radiation, wind speed, ambient temperature, geometry of collector and heat transfer fluid. Design of thermal heat absorber has a crucial role in improving heat transfer rate. Further in the literature, it is observed that effective techniques for heat transfer augmentations are use of extended surfaces, various flow patterns. Each PV cooling technology has some merits and demerits hence it should be selected based upon climatic condition, cooling extent, budgetary constraints and end use of recovered thermal energy. Due to lower heat transfer characteristics of air and water and its effect on electrical performance; motivation has been shifted to PCM, nanofluid and refrigerant based cooling . It is also understood from the literature that impact of cooling technologies on technical, environmental and economical characteristics should be investigated in details and process parameters need to be optimized for further popularization and commercial use.

\section{REFERENCES}

[1] S. P. Sukhatme, Solar Energy: Principles of Thermal Collection and Storage, Tata McGraw Hill Publications , pp71-137, 2008

[2] E. Skoplaki, J.A. Palyvos, on the temperature dependence of photo-voltaic module electrical performance: a review of efficiency/power correlations, Solar Energy 83, pp 614-624, 2009

[3] Kern Jr, E.C., Russell, M. C., Combined photovoltaic and thermal hybrid collector systems. In: Conference Record of the IEEE Photovoltaic Specialists Conference, 1978

[4] T. T. Chow, A review on photovoltaic/thermal hybrid solar technology, Applied Energy 87 , pp 365-379, 2010

[5] Uzma Qureshi, Prashant Baredar, Anil Kumar, Effect of operating parameters on the performance of the hybrid solar PVT collector under different weather condition, International Journal of Science, Environment and Technology, Vol. 3, No 4 , pp $1563-1570,2014$

[6] J.K. Tonui, Y. Tripanagnostopoulos: Performance improvement of $\mathrm{PV} / \mathrm{T}$ solar collectors with natural air flow operation, Solar Energy 82, pp 1-12, 2008

[7] A. Shahsavar, M. Ameri, Experimental investigation and modeling of a direct-coupled PV/T air collector, Solar Energy 84, pp 1938-1958, 2010

[8] H.G. Teo, P.S. Lee, M.N.A. Hawlader, An active cooling system for photovoltaic modules, Applied Energy 90, pp 309-315, 2012

[9] Arvind Tiwari, M.S. Sodha, Parametric study of various configurations of hybrid PV/thermal air collector: Experimental validation of theoretical model, Solar Energy Materials \& Solar Cells 91 , pp 17-28, 2007

[10] A.S. Joshi, A. Tiwari, G.N. Tiwari, I. Dincer, B.V. Reddy, Performance evaluation of a hybrid 
photovoltaic thermal (PV/T) (glass-to-glass) system, International Journal of Thermal Sciences 48, pp 154-164, 2009

[11] Othman, M.Y., Baharudin, Y., Sopian, K., and Nazari M., Performance analysis of a double-pass photovoltaic/thermal (PV/T) solar collector with CPC and fins., Renewable Energy 30, pp 20052017, 2005

[12] Solanki, S.C., Dubey, S., Tiwari, A., Indoor simulation and testing of photovoltaic thermal (PV/T) air collectors, Applied Energy 86, pp 24212428, 2009

[13]A. Shahsavar, M. Ameri, Experimental investigation and modeling of a direct-coupled PV/T air collector, Solar Energy 84, pp 1938-1958, 2010

[14] Goh Li Jin, Hafidz Ruslan, Sohif Mat, Mohd. Yusof Othman,Azami Zaharim Kamaruzzaman Sopian, Experiment Study on Single-pass Photovoltaic-Thermal (PV/T) Air Collector with Absorber, selected topics in system science and simulation in engineering, pp 435-438, 2010

[15] Juwel Chandra Mojumder, Wen Tong Chong, Hwai Chyuan Ong, K.Y. Leong, Abdullah-Al-Mamoon, An experimental investigation on performance analysis of air type photovoltaic thermal collector system integrated with cooling fins design, Energy and Buildings 130, pp 272-285, 2016

[16] H.G. Teo, P.S. Lee , M.N.A. Hawlader, An active cooling system for photovoltaic modules, Applied Energy 90, pp 309-315, 2012

[17] S.M. Bambrook, A.B. Sproul, Maximising the energy output of a PVT air system, Solar Energy 86 pp 1857-1871, 2012

[18] Tonui, J.K., Tripanagnostopoulos, Y., Performance improvement Air-cooled PV/T solar collectors with low cost performance improvements, Solar Energy 81, pp 498-511, 2007

[19] Sarhaddi, F., Farahat, S., Ajam, H., Behzadmehr, A., Mahdavi Adeli, M., An improved thermal and electrical model for a solar photovoltaic thermal (PV/T) air collector, Applied Energy. 87(2010) 2328-2339.

[20] Jin-Hee Kim, Se-Hyeon Park, Jun-Tae Kim, Experimental performance of a photovoltaicthermal air collector, Energy Procedia 48, pp 888 $-894,2014$

[21] H. Bahaidarah, Abdul Subhan, P. Gandhidasan, S. Rehman, Performance evaluation of a PV (photovoltaic) module by back surface water cooling for hot climatic conditions, Energy 59, pp 445-453, 2013

[22] Ahmad Fudholi, Kamaruzzaman Sopian, Mohammad H. Yazdia, Mohd Hafidz Ruslana, Adnan Ibrahim, Hussein A. Kazem , Performance analysis of photovoltaic thermal (PVT) water collectors" Energy Conversion and Management, 78 pp 641-651, 2014

[23] Blessy Joy, J. Philip, Richu Zachariah, Investigations on serpentine tube type solar photovoltaic/ thermal collector with different heat transfer fluids: Experiment and numerical analysis, Solar Energy 140, pp 12-20, 2016

[24] Masoud Rahimi, Ebrahim Karimi, Masomeh Asadi, Peyvand Valeh-e-Sheyda, Heat transfer augmentation in a hybrid microchannel solar cell, International Communications in Heat and Mass Transfer 43, pp 131-137, 2013

[25] K. Touafek, A. Khelifa, M. Adouane, Theoretical and experimental study of sheet and tubes hybrid PVT collector, Energy Conversion and Management 80 , pp 71-77, 2014

[26] Hanene Ben Cheikh El Hocine, Khaled Touafek, Fouad Kerrour, Theoretical and Experimental Studies of a New Configuration of PhotovoltaicThermal Collector, Journal of Solar Energy Engineering, 139 , pp 021012-1-7, 2017

[27] Niccolo Aste, Claudio Del Pero, Fabrizio Leonforte, Thermal-electrical optimization of the configuration a liquid PVT collector, Energy Procedia 30, pp 1-7, 2012

[28] W. J. A. Jayasuriya, A. U. C. D. Athukorala, A. T. D. Perera, M. P. G. Sirimanna, R. A. Attalage, Performance Analysis of Photovoltaic Thermal (Pvt) Panels Considering Thermal Parameters, Proceedings of the ASME 2016 Power Conference POWER2016, Charlotte, North Carolina, pp 1-14, 2016

[29] Nyariki Ondara Wycliffe, David M. Mulati and David M. Maina, Design and Characterization of a Hybrid Flat Plate Photovoltaic-Thermal System, Proceedings of the 2016 Annual Conference on Sustainable Research and Innovation, pp 262-268, 2016

[30] Derrick C. Agbidi, Olusola O. Bamisile, Serkan Abbasoglu, Performance Analysis and Comparison of Photovoltaic, Solar Water Heating and Photovoltaic Thermal Systems, 978-1-5090-37841/16,pp 133-140, 2016

[31] Adnan Ibrahim, M.Y. Othman, M.H. Ruslan, M.A. Alghoul, M.Yahya, And A. Zaharim And K. Sopian, Performance of Photovoltaic Thermal Collector (PVT)With Different Absorbers Design, WSEAS Transactions on Environment and Development, Issue 3, Volume 5, pp 321-330, 2009

[32] Swapnil Dubey, G.N. Tiwari, Thermal modelling of a combined system of photovoltaic thermal (PV/T) solar water heater, Solar Energy 82, pp 602-612, 2008

[33] Swapnil Dubey, Andrew A. O. Tay, Experimental Study of the Performance of Two Different Types of Photovoltaic Thermal (PVT) Modules under Singapore Climatic Conditions, Ash din Publishing Journal of Fundamentals of Renewable Energy and Applications,2, pp 1-6, 2012

[34] A. Fudholi, K. Sopian, M. H. Yazdi, M. H. Ruslan, A. Ibrahim, H. A. Kazem, Performance analysis of photovoltaic thermal (PVT) water collectors, Energy Conversion and Management 78, pp 641651,2014 
[35]N. Aste, C. Del Pero, F. Leonforte, Water PVT collectors performance comparison, Energy Procedia 105, pp $961-966,2017$

[36] T. T. Chow, J. Ji, W. He, Photovoltaic-Thermal Collector System for Domestic Application, Journal of Solar Energy Engineering, 129, pp 205209, 2007

[37] Wei He, Yang Zhang, Jie Ji, Comparative experiment study on photovoltaic and thermal solar system under natural circulation of water, Applied Thermal Engineering 31, pp 3369-3376, 2011

[38] Wei, He, Tin-Tai Chow, Jie Ji, Jianping Lu, Gang Pei, Lok-shun Chan, Hybrid photovoltaic and thermal solar-collector designed for natural circulation of water, Applied Energy 83, pp 199210, 2006

[39] Patrick Dupeyrat,Christophe Me'ne'zo, Matthias Rommel,Hans-Martin Henning, Efficient single glazed flat plate photovoltaic-thermal hybrid collector for domestic hot water system, Solar Energy 85, pp 1457-1468, 2011

[40] R. Santbergen, C.C.M. Rindt, H.A.Zondag, R.J.Ch. van Zolingen, Detailed analysis of the energy yield of systems with covered sheet-and-tube PVT collectors, Solar Energy 84, pp 867-878, 2010

[41] G. Evola, L. Marletta, Exergy and thermos economic optimization of a water-cooled glazed hybrid photovoltaic/thermal (PVT) collector, Solar Energy 107, pp 12-25, 2014

[42] Amna A. Alzaabi, Nadine K. Badawiyeh, Hind O. Hantoush, A. K. Hamid, Electrical/thermal performance of hybrid PV/T system in Sharjah, UAE, International Journal of Smart Grid and Clean Energy, 3, pp 385-389, 2014

[43] Pierrick Haurant, Christophe Ménézo, Leon Gaillard, Patrick Dupeyrat, A numerical model of a solar domestic hot water system integrating hybrid photovoltaic/thermal collectors, 6th International Building Physics Conference, Energy Procedia 78, pp 1991 - 1997, 2015

[44] Stultz, J.W., Wen, L.C., Thermal performance testing and analysis of photovoltaic modules in natural sunlight LSA Task Report 1977, 5101-5131. Jet Propulsion Laboratory, Pasadena, California.

[45] Christopher J. Smith , Piers M. Forster, Rolf Crook, Global analysis of photovoltaic energy output enhanced by phase change material cooling, Applied Energy 126, pp 21-28, 2014

[46] A. Hasan, J. Sarwar, H. Alnoman, S. Abdelbaqi, Yearly energy performance of a photovoltaic-phase change material (PV-PCM) system in hot climate, Solar Energy 146, pp 417-429, 2017

[47] M.J. Huang, P.C.Eames, B.Norton, N.J.Hewitt, Natural convection in an internally finned phase change material heat sink for the thermal management of photovoltaics, Solar Energy Materials \& Solar Cells 95, pp 1598-1603, 2011

[48] Maria C. Browne, Keith Lawlor, Adam Kelly, Brian Norton and Sarah J.McCormack, Indoor characterization of a photovoltaic/ thermal phase change material system, Energy Procedia 70, pp $163-171,2015$

[49] A. Hasan, S.J. McCormack, M.J. Huang, J. Sarwar, B. Norton, Increased photovoltaic performance through temperature regulation by phase change materials: Materials comparison in different climates, Solar Energy 115, pp 264-276, 2015

[50] M.C. Browne, B.Norton, S.J.McCormack, Phase change materials for photovoltaic thermal management, Renewable and Sustainable Energy Reviews 47, pp 762-782, 2015

[51]Ewald Japs, Gerrit Sonnenrein, Stefan Krauter, Jadran Vrabe, Experimental study of phase change materials for photovoltaic modules: Energy performance and economic yield for the EPEX spot market, Solar Energy 140, pp 51-59, 2016

[52]Farouk Hachem , Bakri Abdulhay , Mohamad Ramadan, Hicham El Hage ,Mostafa Gad El Rab, Mahmoud Khaled, Improving the performance of photovoltaic cells using pure and combined phase change materials Experiments and transient energy balance, Renewable Energy 107 , pp 567-575, 2017

[53] Taieb NEHARI, Mohamed BENLEKKAM, Driss NEHARI, Abdelkader YOUCEFI, The Effect of Inclination on the Passive cooling of the solar PV panel by using Phase change Material, International Journal of Renewable Energy Research , pp1434-1441, 2016

[54] Di Su, Yuting Jia, Guruprasad Alva, Lingkun Liu, Guiyin Fang, Comparative analyses on dynamic performances of photovoltaic-thermal solar collectors integrated with phase change materials, Energy Conversion and Management 131, pp 7989, 2017

[55] Ewa Klugmann-Radziemska and Patrycja WcisłoKucharek Photovoltaic module temperature stabilization with the use of phase change materials, Solar Energy 150, pp 538-545, 2017

[56]Sajan Preet, Brij Bhushan, Tarun Mahajan, Experimental investigation of water based photovoltaic/thermal (PV/T) system with and without phase change material (PCM), Solar Energy 155, pp 1104-1120, 2017

[57] Sudarmadji Sudarmadji, Sudjito Soeparman, Slamet Wahyudi, Nurkholis Hamidy, Effects of Cooling Process of $\mathrm{Al}_{2} \mathrm{O}_{3}$-water Nanofluid on Convective Heat Transfer, FME Transactions (2014) 42, 155-161

[58] Madhu. B., Bala Subramanian. E., Nagarajan. P.K., Ravishankar Sathyamurthy, Mageshbabu. D., Improving the Yield of Freshwater and Exergy Analysis of Conventional Solar Still with Different Nanofluids, FME Transactions (2017) 45, 524-530 524

[59]Natasha E. Hjerrild , Sara Mesgari ,Felipe Crisostomo, Jason A. Scott, Rose Amal ,Robert A. Taylor ,Hybrid PV/T enhancement using selectively absorbing $\mathrm{Ag}-\mathrm{SiO} 2 /$ carbon nanofluid, 
Solar Energy Materials \& Solar Cells 147, pp 281-287, 2016

[60] Ali H.A. Al-Waeli, Miqdam T. Chaichan, Hussein A. Kazem , K. Sopian, Comparative study to use nano-( $\mathrm{Al} 2 \mathrm{O} 3, \mathrm{CuO}$, and $\mathrm{SiC})$ with water to enhance photovoltaic thermal PV/T collectors, Energy Conversion and Management 148, pp 963-973, 2017

[61] Nooshin Karami, Masoud Rahimi, Heat transfer enhancement in a PV cell using Boehmite nanofluid, Energy Conversation and Management 86, pp 275-285, 2016

[62] Oussama Rejeb, Mohammad Sardarabadi, Christophe Ménézo, Mohammad PassandidehFard,Mohamed Houcine Dhaou, Abdelmajid Jemni, Numerical and model validation of uncovered nanofluid sheet and tube type photovoltaic thermal solar system, Energy Conversion and Management 110 , pp 367-377, 2016

[63] Shohreh Soltani , Alibakhsh Kasaeian , Hamid Sarrafha , Dongsheng Wen, An experimental investigation of a hybrid photovoltaic/thermoelectric system with nanofluid application, Solar Energy 155, pp 1033-1043, 2017

[64] Dr. Hashim A. Hussien, Dr. Ali H. Noman, Abdulmunem Raad Abdulmunem, Indoor Investigation for Improving the Hybrid Photovoltaic/Thermal System Performance Using Nanofluid (AL2O3-Water), Engg. And Tech. Journal, 33, pp 889-901, 2015

[65] Mohammad Sardarabadi, Mohammad PassandidehFard, Mohammad-Javad Maghrebi, Mohsen Ghazikhani, Experimental study of using both $\mathrm{ZnO} /$ water nanofluid and phase change material (PCM) in photovoltaic thermal systems, Solar Energy Materials \& Solar Cells 161, pp 62-69, 2017

[66] Jee Joe Michael, S. Iniyan, Performance analysis of a copper sheet laminated photovoltaic thermal collector using copper oxide - water nanofluid, Solar Energy 119, pp 439-451, 2015

[67] Muhammad O. Lari, Ahmet Z. Sahin, Design, performance and economic analysis of a nanofluidbased photovoltaic/thermal system for residential applications, Energy Conversion and Management 149 , pp 467-484, 2017

[68] Ali Najah Al-Shamani , K. Sopian , Sohif Mat , Husam Abdulrasool Hasan, Azher M. Abed , M.H. Ruslan, Experimental studies of rectangular tube absorber photovoltaic thermalcollector with various types of nanofluids under the tropical climate conditions, Energy Conversion and Management 124, pp 528-542, 2016

[69] Sardarabadi M, Hosseinzadeh M, Kazemian A, Passandideh-Fard M, Experimental investigation of the effects of using metal-oxides/water nanofluids on a photovoltaic thermal system (PVT) from energy and exergy viewpoints, Energy, doi: 10.1016/j.energy.2017.07.046, 2017

[70]R Gangadevi, B K Vinayagam, S Senthilraja, Experimental investigations of hybrid PV/Spiral flow thermal collector system performance using A12O3/water nanofluid, IOP Conf. Series: Materials Science and Engineering 197 , 012041 doi:10.1088/1757-899X/197/1/012041, 2017

[71]Matin Ghadiri, Mohammad Sardarabadi , Mohammad Pasandideh-fard , Ali Jabari Moghadam, Experimental investigation of a PVT system performance using nanoFerrofluids, Energy Conversion and Management 103, pp 468-476, 2015

[72] Daghigh, R., Ruslan, M.H., Sopian, K.., Advances in liquid based photovoltaic/thermal (PV/T) collectors. Renewable and Sustainable Energy Review. 15 (8), pp 4156-4170, 2011

[73]Hongbing Chen, Saffa B. Riffat, Yu Fu, Experimental study on a hybrid photovoltaic/heat pump system, Applied Thermal Engineering 31, pp 4132-4138, 2011

[74]Huan Liang Tsai, Design and Evaluation of a Photovoltaic/Thermal-Assisted Heat Pump Water Heating System, Energies 7, pp 3319-3338, 2014

[75]Feng Shan, Fang Tang, Lei Cao, Guiyin Fang, Dynamic characteristics modeling of a hybrid photovoltaic-thermal solar collector with active cooling in buildings, Energy and Buildings 78, pp 215-221, 2014

[76] Jinzhi Zhou, Xudong Zhao, Xiaoli Maa, Zhongzhu Qiu, Jie Ji, Zhenyu Du, Min Yu, Experimental investigation of a solar driven direct-expansion heat pump system employing the novel PV/microchannels-evaporator modules, Applied Energy 178, pp 484-495, 2016

[77] Jinzhi Zhou, Xudong Zhao, Xiaoli Maa, Zhenyu Du , Yi Fan, Yuanda Cheng, Xinghui Zhang, Cleardays operational performance of a hybrid experimental space heating system employing the novel mini-channel solar thermal \& PV/T panels and a heat pump, Solar Energy 155, pp 464-477, 2017

[78] Attila Bai, József Popp, Péter Balogh, Zoltán Gabnai, Béla Pályi, István Farkas, Gábor Pintér, Henrik Zsiborács, Technical and economic effects of cooling of monocrystalline photovoltaic modules under Hungarian conditions, Renewable and Sustainable Energy Reviews 60, pp 1086-1099, 2016.

\section{НАЈНОВИЈА КРЕТАҢА У РАЗВОЈУ ТЕХНОЛОГИЈА ХЛАЪЕЊА КОД СОЛАРНИХ ФОТОНАПОНСКИХ СИСТЕМА}

\section{Ј.Б. Сатпуте, Џ. Раџан А.}

Температура фотонапонског модула расте услед апсорбованог инцидентног Сунчевог зрачења да би потом опадала код добијене електричне енергије. Да би се превазишао овај негативан ефекат мора се користити одговарајући материјал за апсорбовање топлоте и одржавање температуре фотонапонског 
модула. Циљ рада је да пружи приказ и омогући разумевање различитих техника хлађења које се користе за побољшање хлађења и електричних перформанси. У раду су истакнути параметри пројектовања и функционисања као што су конфигурација апсорбера, начин протока, брзина протока, климатски услови, интензитет зрачења, брзина ветра, топлотна проводљивост, углачаност, усмереност на елетричне и топлотне карактеристике. Приказани радови обухватају теоријску анализу, компјутерску симулацију, соларни симулатор и теренске експерименте. Наводи се да су правилан избор и коришћење технологије хлађења, као и параметри пројектовања и процеса, кључни елементи за постизање оптималних перформанси соларног фотонапонског система. 